\title{
Identification of SNPs within the PRLR gene and effects on maternal behavior in sheep
}

\author{
L.P. Wang ${ }^{1}$, R.Q. Geng ${ }^{1}$, X.N. Zhang ${ }^{2}$ and W. Sun ${ }^{2}$ \\ ${ }^{1}$ College of Life Science and Technology, Yancheng Teachers University, \\ Yancheng, Jiangsu Province, China \\ ${ }^{2}$ College of Animal Science and Technology, Yangzhou University, Yangzhou, \\ Jiangsu Province, China \\ Corresponding author: L.P. Wang \\ E-mail: Ipwang76@163.com
}

Genet. Mol. Res. 14 (4): 17536-17543 (2015)

Received August 17, 2015

Accepted October 18, 2015

Published December 21, 2015

DOI http://dx.doi.org/10.4238/2015.December.21.26

ABSTRACT. The prolactin receptor gene (PRLR) plays an essential role in maternal behavior. The aim of the study was to detect $P R L R$ mutations in exon 10, using a polymerase chain reaction-single stranded conformation polymorphism method, and to determine the association between mutations in this region with maternal behavior traits in Chinese Hu sheep. Polymorphisms were detected only in the gene region amplified by the primer $\mathrm{P} 3$; three genotypes ( $A A, A B$ and $B B$ ) were observed. The genotype $\mathrm{BB}$ was predominant in the ewe study population, and genotype distributions were in agreement with the Hardy-Weinberg equilibrium ( $P$ $>0.05)$. There was no significant difference between observations for licking and kicking behaviors of $A A$ and $A B$ genotype individuals $(P>0.05)$, but there was a significant difference $(0.01<P \leq 0.05)$, when both were compared with the BB genotype. Significant differences were observed in suckling behavior between $A A$ and $A B$ genotype individuals $(0.01<P$ $\leq 0.05$ ), and the difference between these two genotypes and BB was highly significant $(P \leq 0.01)$. No obvious difference was observed between 
the genotypes in behavior of suckling rejection $(P>0.05)$. These results contribute to methods for selection and breeding through marker-assisted selection for maternal behavior traits in Hu sheep.

Key words: PRLR gene; SNP; Maternal behavior; Hu sheep

\section{INTRODUCTION}

Maternal behavior is increasingly recognized as an important factor in farm animal production. Selection in sheep for increased litter size at birth puts higher demands on the ability of ewes to raise large lambs. Inadequate maternal care invariably leads to early death of offspring because lamb growth and development depend heavily on care provided by the dam (Burfening and Kress, 1993). This is especially true for twins (Nowak, 1996). Several behavior traits in dams play a role in offspring survival and thriftiness. Behavioral interactions between the ewe and her lambs in the very first hour following birth are fundamental to the development of the mother-offspring bond, and the future of the neonate (Lévy, 2002; Shayit et al., 2003). The main factors contributing to the formation of this early bond are licking or grooming of the lamb; suckling; absence of lamb-directed aggression; and cooperation with the lamb's attempts to suck (Lent, 1974; Alexander, 1988; Nowak et al., 1997, 2000). Although maternal behavior differs markedly between breeds, within breeds, mothers show similar, specific maternal responses. However, considerable variation exists in the quality and quantity of these behaviors expressed by individuals within a breed.

Maternal behaviors are heritable and genetically correlated traits (Dwyer, 2007). Although the genetic basis of maternal behaviors is still to be fully determined, maternal behavior can be improved by breeding selection, and a better understanding of the molecular basis underlying individual differences in maternal behavior may assist in the development of selection strategies. Evidence for associations between gene and maternal behavior has been reported (Tanaka, 2002; Tomás et al., 2006; Nishimori et al., 2008; Mileva-Seitz et al., 2012; Avinun et al., 2012); these findings have advanced our understanding of the genetic influences on maternal behavior. It has been reported that PRLR plays an essential role in the induction of the maternal behavior (Lucas et al., 1998; Cui et al., 2007; Chen et al., 2010a). These results clearly establish PRLR as a regulator of maternal behavior.

The Hu sheep is a world-famous breed in South China and is characterized by high fecundity, with an average litter size of 2.29 and a lambing rate of $200-250 \%$ (Wang et al., 2000). Over the last two decades, sheep breeders have selected and bred ewes for increased fecundity traits. However, the relationship between lambing rate and maternal behavior is poorly understood in highly fecund ewes. The aim of this study was to identify genetic variations in the prolactin receptor gene $(P R L R)$ and evaluate the effects of variations on maternal behaviors in Hu sheep.

\section{MATERIAL AND METHODS}

\section{Animals, DNA isolation and behavioral observations}

Eighty-one pure bred Hu sheep ewes were selected from Suzhou sheep-breeding farms in Jiangsu Province, China. Edge tissues of ear samples from ewes were used to extract genomic DNA, using a standard phenol-chloroform extraction protocol (Sambrook et al., 1989).

Prior to lambing, two or three ewes were kept together in a barn; all lambs were born 
indoors. Ewes and their lambs were kept together and ewe behavior during the 72-h period following lambing was monitored continuously. Four maternal behaviors were recorded in ewes: licking of lambs; accepting the lamb at the udder and allowing suckling; kicking at lambs; and rejecting the lamb at the udder (not allowing suckling).

\section{Primer design and PCR amplification}

Based on sheep PRLR mRNA sequences (GenBank accession Nos. AF041257, FJ901298), four pairs of primers were designed to amplify exon 10 (P1-P4; Table 1).

Polymerase chain reaction (PCR) amplification was carried out from 100 ng genomic DNA in a final volume of $20 \mu \mathrm{L}$ containing $1 \mathrm{X}$ reaction buffer; $200 \mu \mathrm{M}$ dNTP; $1 \mathrm{U}$ Taq DNA polymerase (Takara, Dalian, China); $2.5 \mathrm{mM} \mathrm{MgCl}$; $0.5 \mu \mathrm{M}$ of each primer; and $\mathrm{ddH}_{2} \mathrm{O}$. The cycling protocol was $5 \mathrm{~min}$ at $94^{\circ} \mathrm{C} ; 35$ cycles of denaturing at $94^{\circ} \mathrm{C}$ for $30 \mathrm{~s}$, annealing for $30 \mathrm{~s}$, and extending at $72^{\circ} \mathrm{C}$ for $30 \mathrm{~s}$; and a final extension at $72^{\circ} \mathrm{C}$ for $10 \mathrm{~min}$. PCR products were visualized by electrophoresis on 1\% agarose (w/v) gel, using 1X TBE buffer (100 mM Tris, $90 \mathrm{mM}$ boric acid and $1.0 \mathrm{mM}$ EDTA, $\mathrm{pH}$ 8.3) and staining with $200 \mathrm{ng} / \mathrm{mL}$ ethidium bromide.

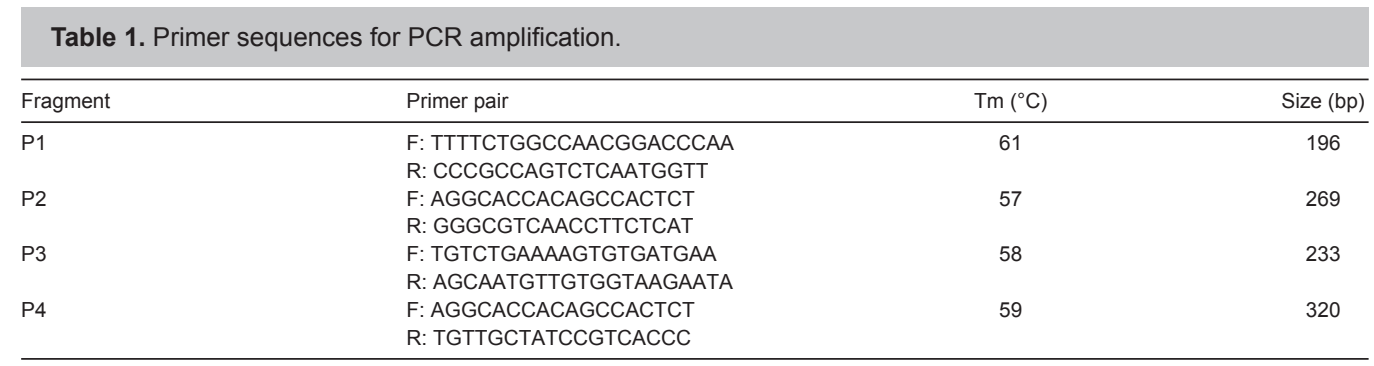

F, forward; R, reverse; Tm, primer melting temperature.

\section{Single-stranded conformation polymorphism (SSCP) analysis}

All PCR products were subjected to SSCP analysis. Aliquots of $3 \mu \mathrm{L} \mathrm{PCR} \mathrm{product} \mathrm{were}$ mixed with $7 \mu \mathrm{L}$ denaturing solution (98\% formamide, $20 \mathrm{mM}$ EDTA, 0.05\% bromophenol blue and $0.05 \%$ xylene cyanol). Following denaturation at $98^{\circ} \mathrm{C}$ for $15 \mathrm{~min}$, samples were placed immediately on ice, then loaded on $10 \%$ acrylamide:bisacrylamide $(29: 1)$ gels. The mixture was electrophoresed using a Mini-PROTEAN apparatus (Bio-Rad, Hercules, CA, USA) in 1X TBE buffer for $10 \mathrm{~h}$ at 120 $\mathrm{V}$, after a pre-run at $240 \mathrm{~V}$ for $5 \mathrm{~min}$. Gels were silver-stained according to the method described by Bassam et al. (1991).

\section{DNA sequencing}

Products amplified by PCR, which represented different PCR-SSCP genotypes including both homozygous and heterozygous genotypes, were purified using a Qiaquick PCR Purification Kit (Qiagen, Germany) and sequenced in the forward and reverse directions using an ABI 3730 sequencer (Applied Biosystems, USA). Nucleotide sequence alignments, translations and comparisons were carried out using Clustal W (Larkin et al., 2007) and MEGA 5.1 (Tamura et al., 2011) software programs. 


\section{Statistical analysis}

Based on the genotypic numbers of $P R L R$ exon 10 locus in the analyzed population, genotypic frequencies, allelic frequencies and Hardy-Weinberg equilibriums were directly calculated. Population genetic indices, including gene homozygosity, gene heterozygosity, and effective allele numbers, were calculated as previously described (Nei and Roychoudhury, 1974; $\mathrm{Nei}$ and $\mathrm{Li}$, 1979). The polymorphism information content (PIC) was calculated as previously described (Botstein et al., 1980).

Associations between genotypes and maternal behavior traits were analyzed using the SPSS software (Version 13.0, SPSS Inc., USA). Effects of genotype on traits were analyzed by the least-square method, as applied in the general linear model (GLM) procedure of SPSS and according to the following statistical model:

$$
\mathrm{Y}_{\mathrm{ijk}}=\mu+\mathrm{G}_{\mathrm{j}}+\mathrm{I}_{\mathrm{k}}+\mathrm{E}_{\mathrm{ijk}}
$$

where $Y_{i j k}$ is the trait measured; $\mu$ is the overall population mean; $G_{j}$ is the fixed effect of the $j$ th genotype; $I_{k}$ is the fixed effect of the kth day observation; and $E_{i j k}$ is the random residual effect of each observation.

\section{RESULTS}

Genomic DNA of postpartum ewes was amplified using four pairs of primers for PRLR gene exon 10. PCR products were consistent with the target fragments and had good specificity, which could be directly analyzed by SSCP. Only the PCR products amplified by primer P3 displayed polymorphisms and three genotypes (AA, AB and $\mathrm{BB}$ ) were detected (Figure 1). Comparisons between nucleotide sequences of different genotypes revealed three SNPs, described as g.284 $\mathrm{C}>\mathrm{T}$, g.337 C>T, and g.339 C>T (Figure 2). These SNPs resulted in two nonsynonymous mutations (g.284 C>T and g.337 C>T mutations caused an amino acid change of Pro $>$ Leu) and one synonymous mutation (g.339 C>T) in PRLR protein.

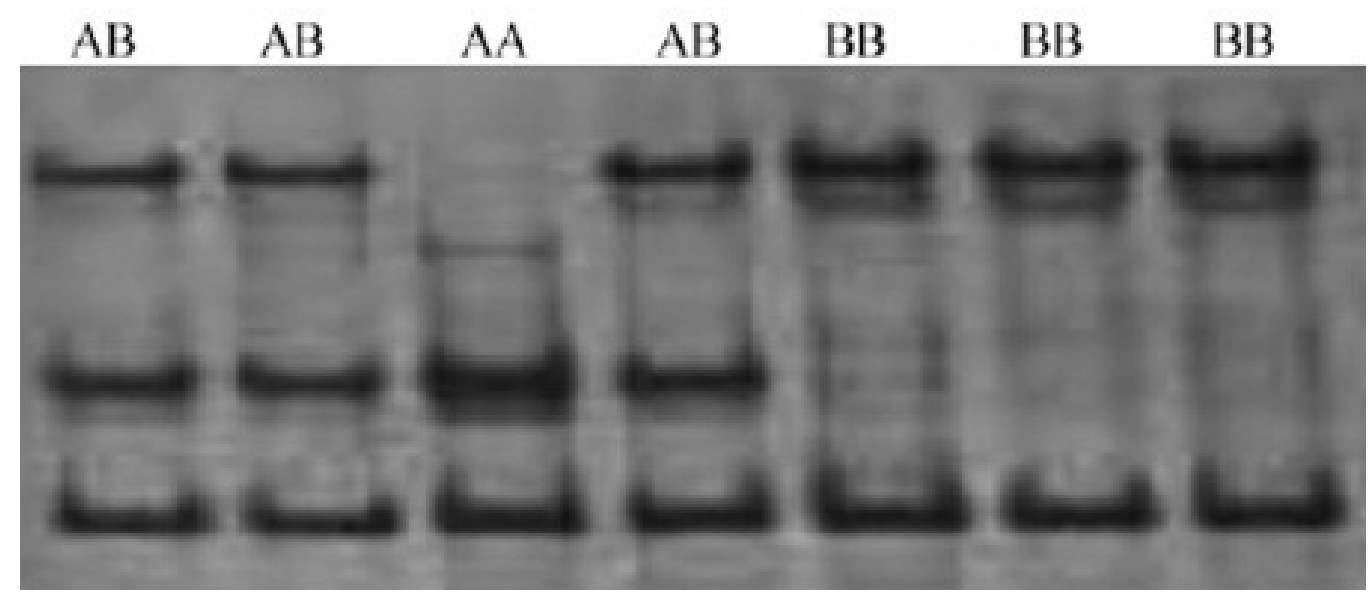

Figure 1. PCR-SSCP patterns of exon 10 within the sheep PRLR gene. 

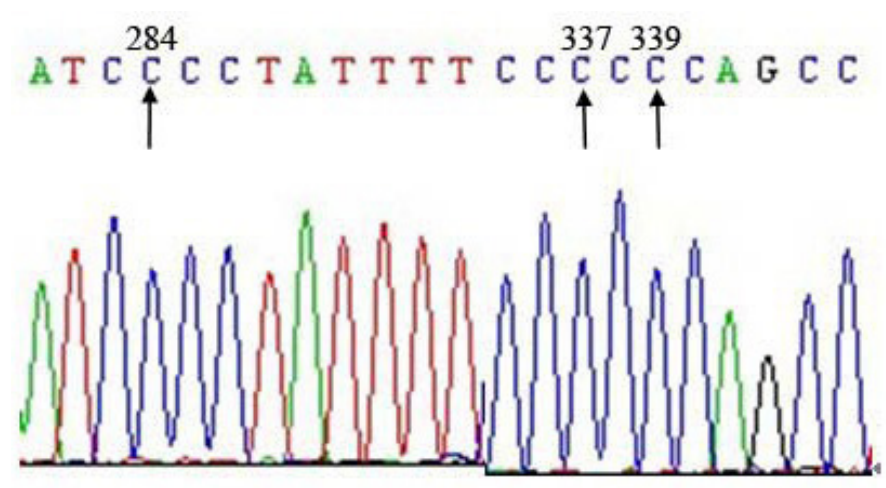

AA

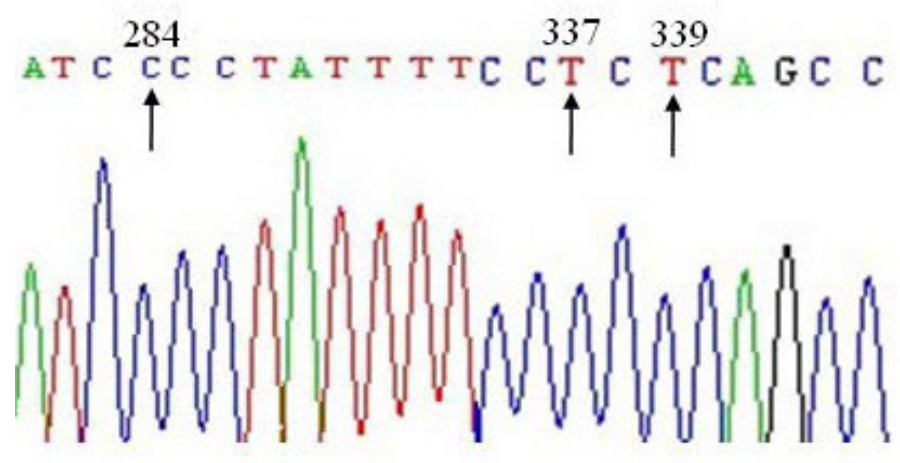

$\mathrm{AB}$

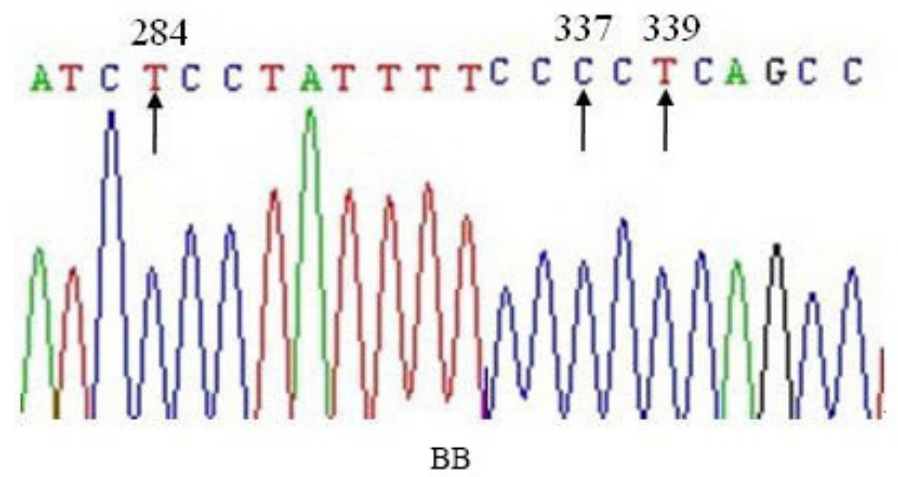

Figure 2. Sequence comparison of different genotypes of the sheep PRLR gene.

Genotypic, allelic frequencies, gene homozygosity and heterozygosity, effective allele numbers, and PIC of PRLR are shown Table 2. BB was the predominant genotype in the ewe population sampled, and chi-square testing showed genotype distributions were in agreement with Hardy-Weinberg equilibrium ( $P>0.05$; Table 2). According to the classification of PIC (low polymorphism if PIC value <0.25; median if $0.25<\mathrm{PIC}<0.5$; high if $\mathrm{PIC}>0.5$ ), the Hu sheep population was at median polymorphic level. 
Table 2. Genotypic distribution and genetic diversity in sheep PRLR exon 10.

\begin{tabular}{|c|c|c|c|c|c|c|c|c|c|c|}
\hline \multicolumn{3}{|c|}{ Observed genotype } & \multirow[t]{2}{*}{ Total } & \multicolumn{2}{|c|}{ Allelic frequency } & \multirow[t]{2}{*}{$\chi^{2}$} & \multirow[t]{2}{*}{$H_{0}$} & \multirow[t]{2}{*}{$H_{\mathrm{E}}$} & \multirow[t]{2}{*}{$N_{\mathrm{E}}$} & \multirow[t]{2}{*}{ PIC } \\
\hline AA & $A B$ & BB & & A & B & & & & & \\
\hline 4 & 34 & 43 & 81 & 0.259 & 0.741 & 0.684 & 0.666 & 0.334 & 1.623 & 0.310 \\
\hline
\end{tabular}

$\chi^{2}$ (HWE), Hardy-Weinberg equilibrium $\chi^{2}$ value; $H_{\mathrm{O}}$, homozygosity; $H_{\mathrm{E}}$, heterozygosity; $N_{\mathrm{E}}$, effective allele numbers; PIC, polymorphism information content.

Because polymorphisms were not detected in P1, P2 and P4 fragments, association analysis did not include these fragments. The relationship between different genotypes of PRLR exon 10 and maternal behaviors in Hu sheep ewes is presented in Table 3. For suckling behaviors, the observations of the three genotypes were gradually decreased. There was no significant difference between observations for licking and kicking behaviors of AA and AB genotype individuals $(P>0.05)$, but there was a highly significant difference $(P \leq 0.01)$ and a significant difference $(0.01$ $<P \leq 0.05)$ between $A A$ and $B B$, and $A B$ and $B B$, respectively, for these behaviors. Significant differences were found in suckling behavior between $A A$ and $A B$ genotype individuals $(0.01<P$ $\leq 0.05$ ), and the difference between these two genotypes and BB genotype was very significant for this behavior $(P \leq 0.01)$. No obvious difference was observed between the three genotypes for the behavior of rejecting suckling $(P>0.05)$. These results demonstrate that partial sequences of PRLR exon 10 exhibit polymorphisms, and that there was some correlation between variances in $P R L R$ and maternal behaviors in Hu sheep.

Table 3. Association between genotypes of PRLR exon 10 and maternal behavior traits in Hu sheep.

\begin{tabular}{lccrr}
\hline Genotype & Licking & Suckling & Kicking & Rejecting suckling \\
\hline AA & $715.88 \pm 17.20^{\mathrm{A}}$ & $392.75 \pm 11.86^{\mathrm{Aa}}$ & $2.75 \pm 0.63^{\mathrm{a}}$ & $5.50 \pm 1.19$ \\
AB & $632.56 \pm 7.72^{\mathrm{A}}$ & $315.00 \pm 9.03^{\mathrm{Ab}}$ & $6.94 \pm 0.71^{\mathrm{a}}$ & $9.03 \pm 1.22$ \\
BB & $635.63 \pm 8.44^{\mathrm{B}}$ & $268.39 \pm 8.41^{\mathrm{BC}}$ & $9.82 \pm 0.89^{\mathrm{b}}$ & $12.27 \pm 1.05$ \\
\hline
\end{tabular}

Values in a column with different letters indicate means that are significantly different $(0.01<P \leq 0.05)$; $a, b, c$ indicate means significantly different $(P<0.05)$; A, B indicate means highly significantly different $(P<0.01)$.

\section{DISCUSSION}

Prolactin is an anterior pituitary peptide hormone involved in many different endocrine activities. It is essential for reproductive performance and is also known to be one of the hormones involved in the induction of maternal behavior (Tanaka, 2002). These actions are mediated by specific receptors in numerous tissues. The prolactin receptor, encoded by $P R L R$, is a member of the growth hormone/prolactin receptor gene family; proteins within this group contain regions of identical sequences. Homozygous and heterozygous mutant nulliparous females in mice, which carry a germ line null mutation of PRLR, show a deficiency in pup-induced maternal behavior (Lucas et al., 1998). Moreover, primiparous heterozygous females exhibit a profound deficit in maternal care when exposed to foster pups. Configural learning, eating, olfactory function, locomotor activity, sexual behavior, and exploration are normal in PRLR mutant mice. Numerous deficiencies in PRLR knockout mice are identified and show that maternal behavior is severely affected in both hemizygous and heterozygous animals (Kelly, 2001). The observation that PRLR knockout mice show a deficiency in pup contact-induced maternal behavior indicates that PRLR plays an essential role in the induction of maternal behavior (Baran et al., 2002). Taken together, 
these results clearly establish $P R L R$ as a regulator of maternal behavior.

In sheep, PRLR has been mapped to chromosome 16 (Jenkins et al., 2000). It is implicated either as a major gene influencing the prolificacy in sheep, or as a gene in close linkage with such a gene, with a role in regulating ovulation in sheep (Chu et al. 2007; Chen et al., 2010b). Based on the important role of $P R L R$ in reproduction, this gene is considered as a possible candidate for high prolificacy of sheep. However, an association between $P R L R$ and maternal behavior in sheep has not been reported thus far. High amino acid variability within the intracellular domain of porcine PRLR has been reported in association with differences in the number of corpus lutea of sows, and the preweaning survivability of piglets (Tomás et al., 2006). The PCR-RFLP (polymerase chain reaction-restriction fragment length polymorphism) technique was applied to analyze single nucleotide polymorphisms (SNPs) of PRLR exon 10 in Minipig and Landrace breeds, to investigate the possible effect of PRLR on sow maternal behavior (Cui et al., 2007). An Nael-RFLP site was detected and three genotypes were identified. Least square analysis between the genotypes and the maternal behavioral traits showed that sows with genotype $A B$ had a significantly higher frequency of lateral-lying-to-other-posture trait, and percentage of sow-terminated nursing trait, compared to sows with $A A$ and $B B$ genotypes. Although no significant differences were found in other behavioral traits, it is possible that allele A was the unfavorable allele for sow maternal behavior. However, in a different study, association analysis showed that neither alleles nor haplotypes had significant association with maternal infanticide behavior of PRLR SNPs in the White DorucxErhulian $\mathrm{F}_{2}$ resource population (Chen et al., 2010a).

In the current study, screening for genetic variations in PRLR exon 10 of Hu sheep revealed the presence of three SNPs, including two nonsynonymous mutations and one synonymous mutation. Significant associations between $P R L R$ genotypes and maternal behavior traits were observed. The results of this study will contribute to effective selection and breeding of Hu sheep, through the development of marker-assisted selection for maternal behavior traits.

\section{ACKNOWLEDGMENTS}

Research supported by the National Natural Science Foundation of China (grant \#31101747); the Natural Science Foundation of Jiangsu Province (grant \#BK20141259); the Six Talent Peaks Project in Jiangsu Province, and the Qing Lan Project of Jiangsu Province.

\section{REFERENCES}

Alexander G (1988). What makes a good mother? Components and comparative aspects of maternal behaviour in ungulates. Proc. Aust. Soc. Anim. Prod. 17: 25-41.

Avinun R, Ebstein RP and Knafo A (2012). Human maternal behaviour is associated with arginine vasopressin receptor $1 \mathrm{~A}$ gene. Biol. Lett. 8: 894-896.

Baran N, Kelly PA and Binart N (2002). Characterization of a prolactin-regulated gene in reproductive tissues using the prolactin receptor knockout mouse model. Biol. Reprod. 66: 1210-1218.

Bassam BJ, Caetano-Anolles G and Gresshoff PM (1991). Fast and sensitive silver staining of DNA in polyacrylamide gels. Anal. Biochem. 196: 80-83.

Botstein D, White RL, Skolnick M, Davis RW (1980). Construction of a genetic linkage map in man using restriction fragment length polymorphisms. Am. J. Hum. Genet. 32: 314-331.

Burfening PJ and Kress DD (1993). Direct and maternal effects on birth and weaning weight in sheep. Small Ruminant Res. 10: 153-163.

Chen CY, Zhu WC, Li PH, Wei N, et al. (2010a). Associations of porcine prolactin (PRL) and prolactin receptor (PRLR) with sow maternal infanticide behavior and litter size in a White Duroc $\times$ Erhualian $\mathrm{F}_{2}$ resource population. China Agr. Sci. 43 : 2347-2354. 
Chen Y, Luo QJ, Yang JQ, Yang FY, et al. (2010b). Relationships between genetic polymorphisms of intron 9 and exon 10 of prolactin receptor gene and litter size of sheep. China Anim. Husbandry Vet. Med. 37: 100-106.

Chu MX, Mu YL, Fang L, Ye SC, et al. (2007). Prolactin receptor as a candidate gene for prolificacy of small tail han sheep. Anim. Biotechnol. 18: 65-73.

Cui SQ, Li JH, Cui WG and Bao J (2007). Preliminary study on the relationship between sow maternal behaviour during early lactation and polymorphism of PRLR gene. Hereditas 29: 47-51.

Dwyer CM (2008). Genetic and physiological determinants of maternal behavior and lamb survival: implications for low-input sheep management. J. Anim. Sci. 86: E246-E258.

Jenkins ZA, Henry HM, Sise JA and Montgomery GW (2000). Follistatin (FST), growth hormone receptor (GHR) and prolactin receptor (PRLR) genes map to the same region of sheep chromosome 16. Anim. Genet. 31: 280.

Kelly PA, Binart N, Lucas B, Bouchard B, et al. (2001). Implications of multiple phenotypes observed in prolactin receptor knockout mice. Front. Neuroendocrinol. 22: 140-145.

Larkin MA, Blackshields G, Brown NP, Chenna R, et al. (2007). Clustal W and Clustal X version 2.0. Bioinformatics, 23: 29472948.

Lent $P$ (1972). Mother-infant relationships in ungulates. Behav. Pap. 1: 14-55.

Lévy F (2002). Neurobiological mechanisms involved in recognition of olfactory signature of the young in sheep. J. Soc. Biol. 196: 77-83.

Lucas BK, Ormandy CJ, Binart N, Bridges RS, et al. (1998). Null mutation of the prolactin receptor gene produces a defect in maternal behavior. Endocrinology 139: 4102-4107.

Mileva-Seitz V, Fleming AS, Meaney MJ, Mastroianni A, et al. (2012). Dopamine receptors D1 and D2 are related to observed maternal behavior. Genes Brain Behav. 11: 684-694.

Nei M and Roychoudhury AK (1974). Sampling variance of heterozygosity and genetic distance. Genetics 76: 379-390.

Nei M and Li WH (1979). Mathematical model for studying genetic variation in terms of restriction endonucleaes. PNAS 76: 5269-5273.

Nishimori K, Takayanagi Y, Yoshida M, Kasahara Y, et al. (2008). New aspects of oxytocin receptor function revealed by knockout mice: sociosexual behaviour and control of energy balance. Prog. Brain Res. 170: 79-90.

Nowak R (1996). Neonatal survival: contributions from behavioural studies in sheep. Appl. Anim. Behav. Sci. 49: 61-72.

Nowak R, Murphy TM, Lindsay DR, Alster P, et al. (1997). Development of a preferential relationship with the mother by the newborn lamb: importance of the sucking activity. Physiol. Behav. 62: 681-688.

Nowak R, Porter RH, Lévy F, Orgeur P, et al. (2000). Role of mother young interactions in the survival of offspring in domestic mammals. Rev. Reprod. 5: 153-163.

Sambrook J, Fritsch EF and Maniatis T. (1989). Molecular Cloning: a Laboratory Manual, 2nd edn. Cold Spring Harbor Laboratory Press, New York.

Shayit M, Nowak R, Keller M and Weller A (2003). Establishment of a preference by the newborn lamb for its mother: the role of opioids. Behav. Neurosci. 117: 446-454.

Tamura K, Peterson D, Peterson N, Stecher G, et al. (2011). MEGA5: Molecular Evolutionary Genetics Analysis using Maximum Likelihood, Evolutionary Distance, and Maximum Parsimony Methods. Mol. Biol. Evol. 28: 2731-2739.

Tanaka M (2002). Brain-specific control of prolactin receptor gene expression correlated with induction of maternal behavior in the rat. J. Reprod. Dev. 48: 103-110.

Tomás A, Casellas J, Ramírez O, Muñoz G, et al. (2006). High amino acid variation in the intracellular domain of the pig prolactin receptor (PRLR) and its relation to ovulation rate and piglet survival traits. J. Anim. Sci. 84: 1991-1998.

Wang YX, Yan YQ, Cheng RH, Wang SY, et al. (2000). Effects of single fecundity selection in Hu sheep. Contemp. Anim. Husbandry 4: 31-32. 